\title{
AKUNTANSI NILAI WAJAR: PERDEBATAN YANG TIDAK BERUJUNG
}

\author{
Nadia Fajriana ${ }^{1}$ \\ Magister Akuntansi Fakultas Ekonomi dan \\ Bisnis \\ Universitas Brawijaya \\ nadyafajriana@gmail.com
}

\author{
Richo Diana Aviyanti² \\ Magister Akuntansi Fakultas Ekonomi \\ dan Bisnis \\ Universitas Brawijaya \\ richodianaavi94@gmail.com
}

\begin{abstract}
ABSTRAK
Artikel ini bermaksud untuk mendiskusikan kembali hasil penelitian-penelitian terdahulu mengenai pro dan kontra penerapan Akuntansi Nilai Wajar (ANW) menggunakan metoda studi literatur. Hasil reviu artikel menemukan bahwa pendukung (pro) penerapan ANW menganggap penerapan ANW sudah tepat karena laporan yang disampaikan lebih relevan. Sedangkan, kelompok penentang (kontra) penerapan ANW menganggap penerapan ANW tidak tepat karena rendahnya reliabilitas dalam penyajian informasi. Kesimpulannya ANW memiliki faktor pendukung utama yaitu kondisi pasar. Jika kondisi pasar aktif, penerapan ANW dapat maksimal karena situasi pasar yang aktif dapat memberikan informasi yang relevan dan reliabel.
\end{abstract}

Kata Kunci : Akuntansi nilai wajar; biaya historis; pengukuran akuntansi.

\section{ABSTRACT}

The intention of this article is to re-discuss about pros and cons of applying the ANW using study of literature method. The pros community said that the application of FV-mensurations presents more relevant information. Meanwhile, the cons community said that the application of FV-mensurations has the low level of reliability of information. The conclusion of applying of FVmensurations depends on market conditions. If the market condition is active, the application of FV-mensurations can be appropriate because the active market situation may provide relevant and reliability information.

Keywords: Accounting; fair value mensuration; historical cost mensuration; accounting mensurations.

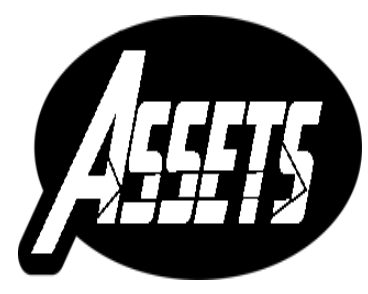

ASSETS

Jurnal Akuntansi dan Pendidikan

Vol. 8 No. 1

Hlmn. 10 - 20

Madiun, April 2019 p-ISSN: 2302-6251 e-ISSN: 2477-4995

Artikel masuk: 06 Desember 2018 Tanggal diterima: 12 April 2019 


\section{PENDAHULUAN}

Laporan keuangan (LK) merupakan sumber informasi bagi pemangku kepentingan perusahaan dan para calon investor. Setiap pos-pos yang terdapat pada LK bisa dijadikan sumber informasi yang relevan untuk pemakainya. Tak hanya itu, pengukuran dalam menilai aset dan liabilitas perusahaan juga sangat penting karena itu akan berdampak pada nilai yang dilaporkan di laporan keuangan. Oleh sebab itu, para standard setter terus berusaha mengembangkan standard-standar akuntansi yang dapat melindungi kepentingan pengguna. Hal ini juga tak terkecuali pada penerapan pengukuran akuntansi nilai wajar (ANW).

Paradigma akuntansi berbasis biaya historis $(\mathrm{ABH})$ telah digantikan oleh paradigma ANW (Barlev \& Haddad, 2003). Perubahan tersebut merefleksikan kebutuhan pengguna akuntansi keuangan serta upaya-upaya yang dilakukan oleh dewan pembuat standar akuntansi untuk membalikkan pola yang menunjukkan penurunan relevansi dari informasi keuangan. $\mathrm{ABH}$ dalam menyiapkan laporan keuangan cenderung mendominasi pada kekuatan dari manajer. Biasanya, historical book value dari aset dan kewajiban hanya memiliki asosiasi tertutup dengan market value, sehingga membuka peluang bagi manajemen untuk memanipulasi laba dan menyembunyikan kurangnya pencapaian manajemen yang sebenarnya (Barlev \& Haddad, 2003). Diperkirakan, penyebab masalah perbankan pada tahun 1980-1990an yang terjadi di Amerika dipicu oleh laporan keuangan yang tidak bergegas melaporkan kerugian, sehingga memunculkan kesepakatan bahwa ABH perlu direkonstruksi ulang (Barth, Landsman, \& Wahlen, 1995; Shanklin, Hunter, \& Ehlen, 2011). Oleh karena itu, standard setter membuat konsep baru yaitu akuntansi nilai wajar (ANW) yang diharapkan dapat memperbaiki kekurangan dari $\mathrm{ABH}$.

ANW dianggap sebagai trend di masa depan sebagai metoda pengukuran (Barlev \& Haddad, 2003; Barth et al., 1995; Sonoto, 2010). Hal ini didukung oleh pernyataan (Barlev \& Haddad, 2003) yang menyatakan bahwa model ANW menjadikan manajemen lebih efektif dalam suatu perusahaan. Laporan keuangan yang didasarkan pada ANW menyediakan informasi yang transparan, karena laporan laba ruginya akan merefleksikan nilai ekonomi yang sebenarnya dari aktivitas bisnis serta laporan neraca merefleksikan aset, kewajiban dan ekuitas yang diukur pada nilai wajar. Model tersebut mengurangi konflik antara pihak pemilik dan agen serta agency cost yang muncul akibat konflik pemilik dan agen. Selain itu, ANW juga meningkatkan efisiensi dari perusahaan tersebut.

Krisis keuangan global tahun 2008 telah berdampak luas ke seluruh perekonomian dunia, khususnya bagi Amerika Serikat (Agha, 2013). Kondisi bursa dan pasar keuangan secara global mengakibatkan nilai investasi menurun, khususnya investasi yang dilakukan negara Eropa dan Amerika Serikat pada tahun 2008-2011, yang menyebabkan para investor mengambil investasinya untuk keamanan (Sukendar, 2012). Hasil investigasi menunjukkan bahwa krisis tidak disebabkan oleh penggunaan ANW, namun disebabkan oleh pengambilan risiko yang cukup besar dan kegagalan lembaga-lembaga perbankan di Amerika Serikat terkait antisipasi probable credit losses, kebimbangan terkait kualitas aset dan turunnya kepercayaan kreditur dan investor (Sukendar, 2012).

Beberapa alasan untuk menerapkan ANW yaitu pertama adalah karena keinginan dari SEC dalam meningkatkan transparansi investasi. Kedua adalah karena komparabilitas dengan perusahaan luar negeri terdaftar di Bursa Amerika. Ketiga adalah karena Eropa mewajibkan penerapan standar internasional berdasarkan akuntansi nilai saat ini ( $P V$-accounting). Keempat adalah karena untuk pengukuran nilai yang lebih akurat dari laporan keuangan (Kartomo, 2008). Penentang penerapan ANW 
menganggap bahwa akuntansi berdasarkan nilai pasar kurang meyakinkan, sehingga mereka tetap meyakini penerapan $\mathrm{ABH}$ lebih unggul karena tingkat reliabilitas yang lebih tinggi. Penentang ANW juga beragumen bahwa estimasi kewajaran nilai aset ( $F V$-asset) dan liabilitas sangat bergantung pada pasar yang likuid untuk membuat laporan keuangan menjadi lebih dipercaya. Namun, pendukung penerapan ANW menentang argumen tersebut dengan menyatakan bahwa penerapan $\mathrm{ABH}$ tidak memperdulikan pergerakan nilai ekonomis dan condong mengabaikan perusahaan dalam menentukan kapan dan akankah mengakui pergerakan tersebut. Masalah ini tentu memicu timbulnya bias dalam penentuan kapan dan akankah dilaporkan serta semakin sulitnya informasi keuangan untuk dipercaya (Siahaan, 2009).

Permasalahan diatas menyebabkan peneliti tertarik untuk melakukan kajian mengenai pro kontra atas penerapan ANW. Artikel ini bermaksud untuk membahas dan menyimpulkan hasil penelitian-penelitian terdahulu mengenai pro dan kontra penerapan ANW menggunakan metoda studi literatur. Penerapan ANW penting untuk dikaji karena dampak dari penerapan ANW akan berpengaruh pada keputusan para investor. Hal ini sesuai penjelasan dari (Barlev \& Haddad, 2003) yang menyatakan bahwa penentuan pengukuran akan berdampak pada valuasi serta pelaporan aset, kewajiban, dimana pada akhirnya akan berdampak pula pada laba.

Laba merupakan satu diantara banyaknya informasi yang relevan terkait penentuan sebuah keputusan berinvestasi bagi para investor (Irawati \& Maya, 2008). Laba per saham juga merupakan satu diantara banyaknya cerminan dari net income perusahaan, yang menunjukkan tingkat pengembalian per lembar sahamnya (Tendelilin, 2010). Investor tentu akan mengharapkan pengembalian yang sesuai dengan harapan atas dana yang telah diinvestasikan pada suatu perusahaan. Oleh karena itu, dengan mengkaji dampak penerapan ANW juga akan membantu pihak investor selaku salah satu pengguna laporan keuangan dalam melindungi kepentingannya.

\section{METODA PENELITIAN}

Penelitian ini menggunakan metoda studi literatur. Penelitian ini menjelaskan mengenai penyebab munculnya pro dan kontra pada penerapan ANW dari berbagai hasil penelitian dan menyimpulkan inti penyebab pro dan kontra dari penerapan ANW.

\section{PEMBAHASAN}

\section{Pengukuran Akuntansi Berdasarkan Nilai Wajar (Fair Value Accounting Mensuration)}

Penerapan $\mathrm{ABH}$ dapat menyebabkan sumber dari data akuntansi menjadi tidak relevan, yang mana hal tersebut menyamarkan laporan keuangan. Hal ini terjadi sebagai akibat dari para akuntan yang lebih memilih reliabilitas dibandingkan dengan relevansi serta mengaplikasikan konservatisme. Paradigma ABH memunculkan keraguan terhadap relevansi nilai dan kebergunaan dari laporan keuangan serta mengubah analisis laporan keuangan menjadi suatu hal yang sulit dan merepotkan (Barlev \& Haddad, 2003).

Berdasarkan permasalahan diatas, munculah konsep sebagai pengganti $\mathrm{ABH}$ yaitu ANW. Salah satu ciri dari penerapan International Financial Reporting Standard adalah banyak menerapkan ANW (Ball, 2006). Pengertian ANW (FVA-mensuration) menurut IFRS 13 revisi 2011 (Fischer, 2011): 
"FV (Fair value) is the price that would be received to sell an asset or paid to transfer a liability in an orderly transaction between market participants at the measurement date."

IFRS 13 menjelaskan bahwa ANW adalah nilai wajar sebagai nilai yang akan didapatkan terkait menjual suatu aset atau nilai yang akan diberikan terkait mengalihkan suatu liabilitas pada sistem bisnis teratur antar pemain pasar pada waktu pengukuran. Terkait penentuan nilai pasar, tidak semua informasi tersedia dalam penentuan harga pasar pada aset dan liabilitas, sehingga FASB dan IASB membuat hirarki nilai wajar yang terdiri dari tiga tingkatan, diantaranya, tingkat satu, assets dan liabilities yang mempunyai market value dengan kinerja cukup bagus; tingkat dua, assets dan liabilities, dimana market value dapat dimaknai dari market value item-item sejenis; tingkat tiga, assets dan liabilities, dimana market value tidak dapat dimaknai, maka perusahaan wajib memakai informasi terbaik yang relevan terkait cara pelaku pasar memegang assets atau liabilities yang akan menilai item tersebut (W. R. Scott, 2015).

Paradigma ANW sedang diperkenalkan ke seluruh dunia (Barlev \& Haddad, 2003). Saat ini Amerika Serikat tidak menerima IFRS, namun mendukung peraturan akuntansi global (Dewanti \& Kiswara, 2015). Sedangkan, di benua Eropa sudah ada aturan untuk menerapkan IFRS mulai tahun 2005. Untuk wilayah ASEAN, hampir seluruhnya telah memakai IFRS seperti Indonesia dan Malaysia pada tahun 2012, yang mana dari 10 anggota ASEAN, hanya Vietnam dan Laos yang belum menerapkan IFRS (Gaffikin, 2003; IFRS.org, 2016). IASB dan FASB menganjurkan, lebih baik menggunakan pengukuran ANW pada laporan keuangan karena laporan yang dihasilkan lebih relevan untuk investor dan kreditor dibandingkan informasi yang menggunakan pengukuran ABH (Ball, 2006). Informasi yang andal akan memudahkan investor dalam menilai aturan baru yang digunakan dalam pengambilan keputusan (Lijing \& LI, 2010). Penerapan ANW diharapkan mampu menjelaskan situasi yang lebih nyata terkait jumlah yang terekam di neraca kepada pengguna laporan keuangan karena telah disesuaikan dengan situasi pasar saat ini pada waktu pelaporan (Sukendar, 2012).

\section{Pro dan Kontra Penerapan Berdasarkan Akuntansi Nilai Wajar}

Telah terjadi banyak perdebatan dalam penerapan ANW. Terdapat pihak yang mendukung (pro) terhadap penerapan ANW, adapula pihak yang menentang (kontra) terhadap penerapan ANW. Dukungan dan penolakan atas penerapan ANW telah diungkapkan oleh (Laux \& Leuz, 2009) yang menyatakan bahwa dalam penerapan ANW, ada sejumlah masalah yang harus diselesaikan oleh standard-setters, yaitu pada tingkat konseptual, standard-setters harus menyeimbangkan antara relevansi dan reliabilitas dari suatu laporan keuangan.

Pendukung ANW menyatakan bahwa pemakaian ANW dapat meningkatkan relevansi informasi akuntansi karena aset dan liabilitas menunjukkan informasi saat ini berdasarkan harga pasar (Barth, 2006; Linsmeier, 2011). Namun, pihak yang menentang penerapan ANW (pendukung $\mathrm{ABH}$ ) mengungkapkan bahwa ANW dapat menciptakan volatilitas laba tanpa perlu meningkatkan informasi yang relevan. Perkiraan ANW melibatkan subjektivitas yang tinggi, ANW juga melibatkan manajer dengan diskresi yang besar dan manajer bisa menggunakan kesempatan diskresionari tersebut ketika melaporkan laba perusahaan (Nissim, 2003).

(Barth et al., 1995) menyatakan bahwa ANW konsisten dengan tujuan utama pelaporan keuangan karena ANW dapat: (a) menyediakan pengguna laporan keuangan mengenai informasi keputusan yang berguna, relevan dan dapat diandalkan; (b) ANW sejalan dengan definisi aset dan kewajiban yang berkonsentrasi 
pada arus masuk dan keluar masa depan atas manfaat ekonomi; dan (c) meringkas penilaian terkini dari time value of money dan risiko. Dengan demikian dapat disimpulkan bahwa ANW memberikan pandangan yang tidak bias terhadap aset dan liabilitas perusahaan pada tanggal pelaporan. Hal ini dikarena item dinyatakan pada laporan keuangan adalah nilai pasar masing-masing pada saat ini. Namun disisi lain, selama krisis keuangan, ANW dianggap menjauhi nilai intrinsik karena masalah likuiditas dan ada beberapa kekhawatiran penggunaan ANW dapat memperburuk kondisi krisis keuangan (Allen \& Carletti, 2008). Berdasarkan perbedaan hasil dari penelitian-penelitian empiris tersebut, berikut akan diuraikan beberapa penelitian terkait pro dan kontra penerapan ANW.

\section{Penelitian yang Pro Terhadap Penerapan Berdasarkan Akuntansi Nilai Wajar (Pendukung Penerapan ANW)}

(Barth et al., 1995) mengemukakan bahwa terdapat relevansi nilai inkremental dari pengungkapan menggunakan ANW untuk sekuritas dan derivatif yang dimiliki oleh bank dan perusahaan asuransi. (Park, Ro, \& Park, 1999) menemukan bahwa adanya relevansi nilai dari penerapan ANW yang diakui untuk sekuritas yang tersedia untuk dijual berdasarkan SFAC 115, serta (Barth, Beaver, \& Landsman, 1996b) menemukan bahwa adanya relevansi nilai untuk komponen discretionary dari loan fair values. (Evans, Hodder, \& Hopkins, 2014) menyatakan bahwa pengukuran ANW dapat memprediksi earnings akuntansi pada masa depan dan (Evans et al., 2014) juga menunjukkan bahwa informasi forward-looking termasuk pengukuran ANW telah menghasilkan jumlah neraca (yields balance sheet amounts) yang dapat memprediksi realisasi relatif kinerja keuangan dimasa depan dan relatif mampu memprediksi efek atau pengaruh penerapan ANW terhadap relevansi nilai (value relevance). Adanya relevansi nilai untuk perbedaan pengukuran kembali aset tidak lancar (intangible asset) berdasarkan Australian Generally Accepted Accounting Principles (GAAP) (Barth \& Clinch, 1998). (Landsman, 1986) melakukan studi terkait apakah investor menilai kewajiban pensiun dan aset-aset terkaitnya, serta kewajiban setelah pensiun, hasilnya adalah investor melakukan penilaian terkait kewajiban pensiun dan aset-aset terkaitnya, serta kewajiban setelah pensiun. (Barth, Beaver, \& Landsman, 1996a; Barth \& Clinch, 1998) melakukan riset terkait relevansi nilai yang berfokus pada sekuritas hutang dan ekuitas. Temuan riset (Barth \& Clinch, 1998) mengindikasikan bahwa para investor melihat estimasi nilai wajar dari sekuritas hutang dan ekuitas lebih informatif daripada menggunakan pengukuran $\mathrm{ABH}$. Temuan tersebut berlaku untuk bank, perusahaan asuransi serta closed-end mutual fund. (Barth et al., 1996a) juga menemukan bahwa para investor melihat estimasi nilai wajar dari pinjaman bank lebih relevan dibandingkan jumlah biaya historisnya. Studi terkait value relevan juga menginvestigasi terkait apakah para investor melihat nilai wajar dari aset tidak berwujud. Studi yang dilakukan oleh (Barth \& Clinch, 1998; Kallapur \& Kwan, 2004) yang melakukan penelitian dengan data-data terkait revaluasi aset berdasarkan GAAP Inggris dan Australia serta estimasi nilai wajar oleh para ahli dalam bidang penilaian merek/brand menemukan bahwa estimasi kewajaran nilai dari intangible assets merefleksikan nilai yang diperhitungkan dari aset tidak berwujud seperti yang diperhitungkan oleh para investor. (Lin \& Peasnell, 2000), melakukan studi apakah estimasi nilai wajar dari aset berwujud jangka panjang menjadi objek perhatian dari para investor, studi yang dilakukan menemukan bahwa figure yang direvaluasi, direfleksikan dalam harga saham dan memiliki relevansi nilai. (Samuelson, 1965) menyatakan bahwa ketika pasar bekerja dengan baik maka harga pasar berfluktuasi secara acak. Jika demikian, harga saat ini adalah prediktor terbaik dari harga di masa depan. (Meythi \& Teresa, 2012) 
melakukan penelitian pada perusahaan PT Hanjaya Mandala Sampoerna Tbk dan PT Kalbe Farma Tbk dengan membandingkan relevansi laporan keuangan antara $\mathrm{ABH}$ dan general price level accounting atau harga pasar, dengan tahun penelitian 2000-2003. Hasil dari penelitian tersebut mengungkapkan bahwa ada ketidaksamaan antara nilai historis dan nilai pasar selama periode inflasi. Nilai pasar lebih relevan dan mendukung informasi lebih cepat pada pemakai laporan keuangan.

(Zelmiyanti, 2014) menyatakan bahwa penerapan ANW telah mengurangi adanya pengakuan kewajiban dan beban yang tinggi dalam laporan keuangan. Namun, adanya ketidakpastian pada perusahaan menyebabkan konservatisme tidak dapat dilepaskan secara penuh. Sifat konservatisme merupakan pembawaan dari $\mathrm{ABH}$ (Barlev \& Haddad, 2003). Sehingga, IFRS mengganti konservatisme dengan prudence (prinsip kehati-hatian perusahaan dalam kondisi ketidakpastian).

Berdasarkan hasil penelitian-penelitian tersebut didapatkan bahwa para pendukung penerapan ANW menganggap ANW lebih unggul terkait relevansinya. ANW lebih mampu mengungkapkan dan memprediksi bagaimana kondisi keuangan suatu perusahaan di periode selanjutnya. Selain itu, penerapan ANW juga menghasilkan informasi yang relevan terkait penentuan keputusan oleh pemakai laporan keuangan, salah satunya investor. Hal ini dikarenakan, informasi yang disampaikan di dalam laporan keuangan merupakan nilai-nilai yang menunjukkan aset atau liabilitas perusahaan dengan nilai pasarnya atau nilai wajarnya.

\section{Penelitian yang kontra Terhadap Penerapan Berdasarkan Akuntansi Nilai Wajar (Menentang ANW)}

(Penman, 2007) menyatakan bahwa jika benar ANW secara konseptual lebih baik, namun implementasinya bisa gagal dan seluruh proses penilaian menjadi kurang andal ketika hubungan antara exit prices dan nilai wajar shareholder tidak berlaku. (Krumwiede, 2008) menyatakan bahwa walaupun ANW memiliki maksud yang baik, namun ANW dapat menjadikan manajemen memiliki perkiraan yang salah karena ANW dapat berlandasakan pada prakira dan asumsi yang kurang tepat, serta jika manajer diasumsikan memiliki sikap oportunistik maka manajer dapat memperoleh benefit dari penilaian dan prakira yang dipakai pada tahap manipulasi dan manajer dapat mengelola angka nilai akuntansi dengan tujuan untuk mencapai tujuannya yaitu angka pendapatan yang diharapkan. (Beaver \& Demski, 1979) menyatakan bahwa ketika nilai wajar tidak dapat didefinisikan secara jelas maka digunakanlah asumsi atau perkiraan, dan kemungkinan akan mengambil satu di antara hal berikut: 'entry price', 'exit price' atau 'value in use'. (Benston, 2008) membuktikan bahwa meskipun SFAS 157 telah menetapkan penggunaan exit price dalam ANW, dalam beberapa kasus, value in use dan entry price digunakan sebagai gantinya. Selain itu, meskipun biaya transaksi harus dikeluarkan dari pertimbangan nilai wajar, namun kenyataan seringkali tidak demikian. (Dichev \& Tang, 2008) menyatakan bahwa ANW mengurangi keinformatifan laba karena perubahan nilai wajar tidak dapat diprediksi dan inklusi, sehingga lebih sulit untuk mengidentifikasi komponen multiple earnings. (Scott, 2010) menyatakan bahwa nilai wajar mengharuskan bank untuk mencatat kerugian yang probabilitasnya masih ambigu atas keterjadiannya dan ini menyebabkan volatilitas yang berlebihan. Selain itu, salah satu dari beberapa penelitian di sektor keuangan, menyatakan bahwa tidak ada relevansi nilai tambahan yang signifikan untuk pengungkapan SFAS 107 (Simko, 1999), terutama karena tidak relevannya aktivitas keuangan untuk perusahaan-perusahaan, sehingga managerial discretion top executives dapat melakukan valuation models yang dapat digunakan untuk meningkatkan kepentingan pribadi (Shalev, Zhang, \& Zhang, 2013). Menggunakan 
akuntansi mark-to-market tentu akan berdampak pada volatilitas laporan keuangan perusahaan. Tentu ini akan mempersulit dalam hal memastikan laba dan rugi perusahaan yang disebabkan oleh pengambilan keputusan bisnis yang dipilih oleh manajemen atau perubahan fluktuatif pasar (Sukendar, 2012). Penerapan ANW juga dapat berdampak pada terjadinya fraud, karena terdapat empat celah dalam ANW, diantaranya penentuan besaran nilai wajar, tidak tersedianya informasi pasar dalam menentukan harga saat ini, penggunaan pendekatan penghasilan dapat menimbulkan celah dalam memperhitungkan nilai harapan pasar saat ini atas nilai dimasa depan, dan penentuan estimasi biaya pengganti karena dalam penentuan estimasi biaya pengganti cukup sulit dalam menentukan kebenaran atas nilai tersebut (Nugrahani, 2014).

Berdasarkan hasil penelitian empiris dari (Sodan, 2015) menunjukkan bahwa ANW tidak sepenuhnya baik, terutama pada negara dengan kondisi pasar yang kurang likuid. Sodan (2015) membuktikan bahwa perusahaan dan perbankan di 17 negara di Eropa Timur yang tercatat di Amadeus, Worldscope and Bankscope pada tahun 2000 sampai 2011 menunjukkan hasil bahwa pendapatan yang diukur dengan ANW memiliki kualitas agregat yang rendah, keuntungan (kerugian) bersih yang dilaporkan pada aset dengan ANW melalui laporan laba rugi bank kurang dalam menjelaskan variasi ukuran kualitas laba. Hasil tersebut mengindikasikan bahwa ANW tidak selamanya sesuai diterapkan dalam segala kondisi. Terdapat kondisi yang kurang tepat menerapkan ANW seperti yang telah dijelaskan oleh (Sodan, 2015) bahkan terdapat kondisi dimana penerapan ANW tidak berpengaruh seperti hasil penelitan empiris dari (Amaefule, Okoye, Kalu, \& Nwosu, 2018).

(Amaefule et al., 2018) mengungkapkan bahwa penerapan ANW pada perusahaan sektor pertanian, konglomerat, konstruksi, barang konsumsi, layanan keuangan, kesehatan, teknologi informasi, barang industri, sumber daya alam, minyak dan gas serta layanan yang terdaftar di Bursa Efek Nigeria menunjukkan bahwa tidak ada perbedaan penerapan dari ANW dan ABH yang dilihat dari laba setelah pajak, laba per saham, dan Return of Equity. Hal ini mengindikasikan bahwa penerapan ANW tidak berdampak baik dan juga tidak berdampak buruk dalam pengukuran akuntansi. (Amaefule et al., 2018) juga mengungkapkan bahwa penerapan ANW perlu ditinjau kembali mengenai realistis nilai yang dihasilkan dengan pengukuran nilai wajar. Sependapat dengan dengan itu, (Khomsantun, 2016) mengemukakan bahwa sampel perusahaan yang terdiri dari perusahaan non-keuangan yang tercatat di BEI pada saat sebelum dan sesudah konvergensi PSAK 13, 16, 19, dan 55 menunjukkan bahwa tidak ada peningkatan daya banding sebelum dan sesudah implementasi PSAK 13, 16, 19,dan 55 kecuali aset tetap. Hal ini mengindikasikan bahwa penerapan ANW masih sulit diterapkan karena dianggap kurang handal dalam menyajikan informasi.

Berdasarkan hasil penelitian-penelitian tersebut diketahui bahwa para penentang penerapan ANW menganggap bahwa ANW kurang reliabel. Para penentang penerapan ANW (pendukung penerapan $\mathrm{ABH}$ ) menganggap bahwa nilai atau informasi yang diukur menggunakan ANW tidak memberikan informasi yang handal. Hal ini dikarenakan penentuan nilai wajar dari sebuah aset atau liabilitas terkadang masih ambigu, hal tersebut sesuai dengan penjelasan dari (Beaver \& Demski, 1979) yang menyatakan bahwa ketika nilai wajar tidak dapat didefinisikan secara jelas maka digunakanlah asumsi atau perkiraan, dan kemungkinan akan mengambil satu di antara hal berikut: 'entry price', 'exit price' atau 'value in use'. Perkiraan dari penentuan nilai wajar ini dapat mengakibatkan informasi yang disampaikan menjadi ambigu dan tidak dapat merefleksikan kondisi suatu perusahaan. Selain itu, hasil penelitian empiris dari (Amaefule et al., 2018; Khomsantun, 2016; Sodan, 2015) menunjukkan 
bahwa penerapan ANW tidak selamanya berpengaruh baik sebagai metoda pengukuran akuntansi.

\section{SIMPULAN}

Pada intinya, hasil pembahasan menunjukkan bahwa terdapat pihak yang pro dan kontra terkait penerapan ANW. Standard-setters terus menerus meningkatkan penerapan konsep ANW karena ANW dianggap mampu menyelesaikan masalah akuntansi saat ini (Scott, 2015). Namun, ANW terlalu peka terhadap pasar yang mengakibatkan semakin sulit untuk memastikan laba dan rugi yang diakibatkan oleh keputusan bisnis atau perubahan di pasar, termasuk volatility kinerja lembaga.

Terdapat beberapa asumsi yang digunakan dalam penerapan ANW, diantaranya kunci utama dalam penerapan ANW adalah kondisi pasar. Jika pasar aktif maka dapat menghasilkan informasi yang relevan dan reliabel. Sedangkan, jika pasar tidak aktif, maka informasi yang dihasilkan tidak fair sehingga informasi yang dihasilkan tidak relevan dan reliabel (Sonoto, 2010). Hal serupa juga dinyatakan oleh (Roekhudin, 2018) yang menyatakan bahwa pengukuran ANW harus didasarkan pada dugaan bahwa harga pasar dapat dilacak di pasar yang aktif. Jika harga tidak mampu dilacak, maka harga pasar yang digunakan adalah harga yang mungkin ditawarkan oleh market participants (pembeli) yang akan dipakai sebagai penilaian assets atau liabilities. Maka, intinya adalah pengukuran assets atau liabilities berdasarkan ANW harus menggunakan exit price. Hal ini dipaparkan juga didalam SFAS 157 dan IFRS 13, ANW adalah pengukuran berbasis pasar, bukan berdasarkan nilai yang dikembangkan entitas (Nugrahani, 2014).

(Sonbay, 2010) menyatakan bahwa penerapan ABH dapat mengurangi aspek kualitas relevansi sehingga muncul ANW untuk mengatasi kekurangan dari $\mathrm{ABH}$. Namun, penerapan ANW tidak sepenuhnya bisa membantu dalam pengambilan keputusan karena kurang dalam hal reliabilias. Hal inilah yang menyebabkan perdebatan dalam penerapan ANW, sehingga perusahaan belum sepenuhnya menerapkan ANW. (Choy, 2006) menjelaskan bahwa FASB dan IASB percaya dan yakin bahwa kemampuan nilai pasar adalah estimator atau penduga yang efisien dan tidak bias dari arus kas masa depan. Namun, (Choy, 2006) juga menyatakan bahwa situasi tersebut dapat dicapai jika dua kondisi dapat dipenuhi: (1) ada harga pasar yang tidak dapat dipengaruhi oleh manajemen perusahaan (meskipun pasar tidak kompetitif sempurna), dan (2) harga pasar dapat diamati secara independen sebagai estimator atau penduga yang akurat untuk pasar yang likuid. Hal ini juga diperkuat dengan pendapat (Mahmudah, 2013) yang melakukan studi menggunakan dua prespektif yang berbeda. Studi tersebut menyatakan bahwa jika dilihat berdasarkan pengukuran maka penerapan ANW akan meningkatkan relevansi informasi yang diperlukan oleh investor, namun terdapat batasan terkait reliabilitas. Adanya trade off antara konsep relevansi dan reriabilitas pada penerapan ANW yang cenderung mengutamakan relevansi dan mengorbankan reliabilitas mengakibatkan laporan keuangan sulit diaudit, sehingga perlu adanya instrumen tepat pada konsep ANW agar dapat diukur secara reliabel.

Berdasarkan kesimpulan dari seluruh hasil penelitian maka didapatkan bahwa penerapan ANW tidak hanya bersifat pro dan kontra, melainkan juga netral. Hal ini dapat ditunjukkan dari hasil penelitian dari (Amaefule et al., 2018; Khomsantun, 2016) bahwa penerapan ANW juga tidak berdampak apa-apa pada peningkatan informasi yang dihasilkan. Meski memiliki sisi pro, kontra, dan netral dalam perdebatannya, namun penerapan ANW tidak lepas dari faktor pendukung disekitarnya, yaitu kondisi 
pasar (Choy, 2006; Nugrahani, 2014; Roekhudin, 2018; Sonbay, 2010; Sonoto, 2010); (Amaefule et al., 2018). Jika kondisi pasar aktif, maka penerapan ANW dapat berjalan secara maksimal. Hal ini dikarenakan ANW membutuhkan kondisi pasar yang aktif untuk memberikan informasi yang relevan dan reliabel karena ANW menitikberatkan pada pengukuran berbasis pasar. Namun jika kondisi pasar tidak mendukung maka penerapan ANW tidak dapat berjalan secara maksimal, bahkan mungkin tidak berdampak baik dalam penyajian laporan keuangan, seperti hasil penelitian dari (Sodan, 2015). Maka dari itu, perdebatan tentang penerapan ANW tidak akan ada habisnya karena adanya perbedaan aspek sosial, budaya, geografis, ekonomi di setiap negara yang dapat mempengaruhi kondisi pasar yang diteliti.

\section{DAFTAR PUSTAKA}

Agha, R. Z. (2013). Agha: Pengaruh Krisis Subprime Mortgage Terhadap Indikator Return Saham Industri. Jurnal TEKUN, IV(01), 143-157.

Allen, F., \& Carletti, E. (2008). Mark-to-market accounting and liquidity pricing. Journal of Accounting and Economics, 45, 358-378. https://doi.org/10.1016/j.jacceco.2007.02.005

Amaefule, L. I., Okoye, E. I., Kalu, E. O., \& Nwosu, S. U. (2018). Fair Value Measurement versus Historical Cost Accounting : A Comparative Effect on Firms ' Performance in Nigeria, 9(10), 165-175.

Ball, R. (2006). International Financial Reporting Standards (IFRS): pros and cons for investors. Accounting and Business Research, 36, 5-27. https://doi.org/10.1080/00014788.2006.9730040

Barlev, B., \& Haddad, J. R. (2003). Fair value accounting and the management of the firm. Critical Perspectives on Accounting, 14, 383-415. https://doi.org/10.1016/S1045-2354(02)00139-9

Barth, M. E. (2006). Including estimates of the future in today's financial statements. Accounting Horizons, 20(3), 271-285. https:/ / doi.org/10.2308/acch.2006.20.3.271

Barth, M. E., Beaver, W. H., \& Landsman, W. R. (1996a). Value-relevance of banks' fair value disclosures under SFAS No. 107. Accounting Review, 71(4), 513-537.

Barth, M. E., Beaver, W. H., \& Landsman, W. R. (1996b). Value Relevance of Banks' Value Disclosures SFAS No. 107 under Fair. Journal of Accounting, Auditing $\mathcal{E}$ Finance, 71(4), 513-537. https:/ / doi.org/10.1177/0148558X0301800103

Barth, M. E., \& Clinch, G. (1998). Revalued Financial, Tangible, and Intangible Assets: Associations with Share Prices and Non-Market-Based Value Estimates. Journal of Accounting Research, 36, 199-233.

Barth, M. E., Landsman, W. R., \& Wahlen, J. M. (1995). Fair value accounting: Effects on banks' earnings volatility, regulatory capital, and value of contractual cash flows. Journal of Banking and Finance, 19, 557-605. https://doi.org/10.1016/03784266(94)00141-O

Beaver, W. H., \& Demski, J. S. (1979). The Nature of Income Measurement. The Accounting Review, 54(1), 38-46. https:// doi.org/10.2307/246232

Benston, G. J. (2008). The shortcomings of fair-value accounting described in SFAS 157. Journal of Accounting and Public Policy, 27, 101-114. https:// doi.org/10.1016/j.jaccpubpol.2008.01.001

Choy, A. K. (2006). Fair Value as a Relevant Metric: A Theoretical Investigation, 1-56.

Dewanti, D. K., \& Kiswara. (2015). Studi Perbandingan Tingkat Kepatuhan Adopsi Intrnational Financial Reporting Standard (IFRS ) di 12 Negara. Diponegoro Journal Of Accounting, 4(3), 1-14.

Dichev, I. D., \& Tang, V. W. (2008). Matching and the changing properties of 
accounting earnings over the last 40 years. Accounting Review, 83(6), 1425-1460. https:// doi.org/10.2308/accr.2008.83.6.1425

Evans, M. E., Hodder, L., \& Hopkins, P. E. (2014). The predictive ability of fair values for future financial performance of commercial banks and the relation of predictive ability to banks' share prices. Contemporary Accounting Research, 31(1), 13-44. https://doi.org/10.1111/1911-3846.12028

Fischer, D. T. (2011). IFRS 13 - Fair Value Measurement. Praxis Internationalen Rechnungslegung. https:// doi.org/10.1289/image.ehp.v119.i03

Gaffikin, M. (2003). Accounting Theory: Research, Regulation and Accounting Practice. Accounting Forum.

IFRS.org. (2016). IFRS - Who uses IFRS Standards? IFRS Standard Filing Profile Project. Retrieved from https://www.ifrs.org/use-around-the-world/use-of-ifrsstandards-by-jurisdiction/

Irawati, Z., \& Maya, A. (2008). Analisis Perataan Laba (Income Smoothing) : Faktor yang Mempengaruhinya dan Pengaruhnya Terhadap Return dan Risiko Saham Perusahaan Go Public di Bursa Efek Jakarta. BENEFIT: Jurnal Bisnis Dan Manajemen, 33-47.

Kallapur, S., \& Kwan, S. Y. S. (2004). The Value Relevance and Reliability of Brand Assets Recognized by U.K. Firms. Accounting Review, 79(1), 151-172. https://doi.org/10.2308/accr.2004.79.1.151

Kartomo, R. (2008). Transformasi Penerapan Nilai Wajar (Fair Value) \& Implikasinya.

Khomsantun, S. (2016). Jurnal riset akuntansi \& keuangan. Jurnal Riset Akuntansi Keuangan, 4(2), 01-21. https:/ / doi.org/10.17509/jrak.v4i3.4670

Krumwiede, T. (2008). Why Historical Costs Accounting Makes Sense. Strategic Finance, 33-39.

Landsman, W. R. (1986). An Empirical Investigation of Pension Fund Property Rights. The Accounting Review, 61(4), 662-691. https://doi.org/10.1016/j.ymeth.2009.04.009

Laux, C., \& Leuz, C. (2009). The crisis of fair-value accounting: Making sense of the recent debate. Accounting, Organizations and Society, 34, 826-834. https://doi.org/10.1016/j.aos.2009.04.003

Lijing, \& LI, B. (2010). The role of fair value accounting for investment in securities: Evidences from the Chinese banking industry. International Research Journal of Finance and Economics, (60), 86-93. https:// doi.org/10.1109/ICMSS.2010.5576527

Lin, Y. C., \& Peasnell, K. V. (2000). Fixed asset revaluation and equity depletion in the UK. Journal of Business Finance and Accounting, 27(3-4), 359-394. https://doi.org/10.1111/1468-5957.00317

Linsmeier, T. J. (2011). Financial reporting and financial crises: The case for measuring financial instruments at fair value in the financial statements. Accounting Horizons, 25(2), 409-417. https:/ / doi.org/10.2308/acch-10024

Mahmudah, H. (2013). Trade Off Relevance dan Reliability: Isu IFRS. JRAK, 2(2), 84-89.

Meythi, \& Teresa, S. (2012). Historical Cost dan General Price Level Accounting: Analisis Relevansi Indikator Keuangan. Jurnal Akuntansi, 4(2), 115-134.

Nissim, D. (2003). Reliability of banks' fair value disclosure for loans. Review of Quantitative Finance and Accounting, 20, 355-384. https://doi.org/10.1023/ A:1024072317201

Nugrahani, C. (2014). Fair value dan potensi fraud. Kiat BISNIS, 5(5), 325-333.

Park, M. S., Ro, B. T., \& Park, T. (1999). Fair Value Disclosures for Investment Securities and Bank Equity: Evidence from SFAS No. 115. Journal of Accounting, Auditing $\mathcal{E}$ Finance. https://doi.org/10.1177/0148558X9901400311 
Penman, S. H. (2007). Financial reporting quality: is fair value a plus or a minus? Accounting and Business Research, 33-44. https://doi.org/10.1080/00014788.2007.9730083

Roekhudin. (2018). Auditors Response towards Auditing of Fair Value. The Indonesian Journal Of Accounting Research, 21(1), 23-46.

Samuelson, P. A. (1965). Proof That Properly Anticipated Prices Fluctuate Randomly, Industrial Management Review. Industrial Management Review, 6(2), 41-49.

Samuelson, P. A. (2015). Proof that Properly Anticipated Prices Fluctuate Randomly. https://doi.org/10.1142/9789814566926_0002

Scott, I. E. (2010). Fair Value Accounting : Friend or Foe? William \& Mary Business Law Review, 1(2), 489-542.

Scott, W. R. (2015). Financial accounting theory. Prentice Hall Canada. https://doi.org/10.1016/j.jbiomech.2013.09.028

Shalev, R., Zhang, I. X., \& Zhang, Y. (2013). CEO Compensation and Fair Value Accounting: Evidence from Purchase Price Allocation. Journal of Accounting Research. https://doi.org/10.1111/1475-679X.12015

Shanklin, S. B., Hunter, D. R., \& Ehlen, C. R. (2011). A Retrospective View Of The IFRS' Conceptual Path And Treatment Of Fair. Journal of Business \& Economics Research, $9(3), 23-28$.

Siahaan, H. (2009). Implikasi dan Permasalahan dalam Mengimplementasikan Konsep Nilai Wajar Dalam Kondisi Ekonomi Saat. Retrieved from http:/ / dfhpartners.id/id/2017/01/19/implikasi-dan-permasalahan-dalammengimplementasikan-konsep-nilai-wajar-dalam-kondisi-ekonomi-saat-i/

Simko, P. J. (1999). Financial Instrument Fair Values and Nonfinancial Firms. Journal of Accounting, Auditing $\mathcal{E}$ Finance, 247-274. https://doi.org/10.1177/0148558X9901400305

Sodan, S. (2015). The Impact of Fair Value Accounting on Earnings Quality in Eastern European Countries. Procedia Economics and Finance, 32, 1769-1786. https:// doi.org/10.1016/s2212-5671(15)01481-1

Sonbay, Y. Y. (2010). Perbandingan biaya historis dan nilai wajar. Kajian Akuntansi, 2(1), $1-8$.

Sonoto, J. F. (2010). Isu Global Konvergensi Ifrs: Masalahpengukunanmenggunakan, $2(2), 139-151$.

Sukendar, H. (2012). Konsep Nilai Wajar (Fair Value) dalam Standar Akuntansi Berbasis IFRS di Indonesia Apa dan Bagaimana? Binus Business Review, 3(1), 93106. https:// doi.org/10.21512/bbr.v3i1.1286

Tendelilin, E. (2010). Portofolio dan Investasi Teori dan Aplikasi. Yogyakarta: Kanisius. https://doi.org/10.2753/MIS0742-1222260306

Zelmiyanti, R. (2014). Perkembangan Penerapan Prinsip Konservatisme dalam Akuntansi. JRAK, 5(1), 561-565. 